\title{
Risks to REDD+: potential pitfalls for policy design and implementation
}

\author{
LASSE LOFT ${ }^{1 *}$, THUY THU PHAM ${ }^{2}$, GRACE YEE WONG ${ }^{34}$, \\ MARIA BROCKHAUS ${ }^{3}$, DUNG NGOC LE ${ }^{2}$, \\ JANUARTI SINARRA TJAJADI ${ }^{3}$ AND CECILIA LUTTRELL ${ }^{3}$ \\ ${ }^{1}$ Leibniz Centre for Agricultural Landscape Research (ZALF), Eberswalder Straße 84, 15374 Müncheberg, \\ Germany, ${ }^{2}$ Center for International Forestry Research (CIFOR), N17A Nguyen Khang Street, Hanoi 10000, \\ Vietnam, ${ }^{3}$ Center for International Forestry Research (CIFOR), Jalan CIFOR, Situ Gede, Bogor Barat 16115, \\ Indonesia and ${ }^{4}$ Center for Southeast Asian Studies, Kyoto University 46, Shimoadachi-cho, Yoshida, Sakyo-ku, \\ Kyoto 606-8501, Japan
}

Date submitted: 22 October 2015; Date accepted: 8 September 2016; First published online 2

November 2016

THEMATIC SECTION

Forest Ecosystem Services

\section{SUMMARY}

International negotiations for reducing emissions from deforestation and forest degradation and the enhancement of forest carbon stocks (REDD+) under the UN Framework Convention on Climate Change (UNFCCC) were finally concluded in 2015. However, due to the complex design and implementation processes of REDD+ policies and measures, including benefit sharing at national and subnational levels, several challenges exist for sustainably reducing emissions while simultaneously managing the provision of social and environmental side-objectives. We review the realities of REDD+ implementation in 13 REDD+ candidate countries and the risks related to REDD+ policies and benefit sharing based upon a synthesis of the findings presented in 'country profiles' that were developed between 2009 and 2013 as part of the Center for International Forestry Research's (CIFOR) Global Comparative Study on REDD+. We find that REDD+ policies in all countries studied are at high risk of ineffectiveness, inequity and inefficiency. By classifying these risks and understanding not only their impacts on different stakeholder groups, but also the consequences for achieving specific objectives, countries can identify solutions in order to address these shortcomings in their implementation of REDD+.

Keymords: REDD+, governance, benefit sharing, carbon rights, risks, multilevel governance, policy implementation, climate change

\section{INTRODUCTION}

Reducing emissions from deforestation and forest degradation $(\mathrm{REDD}+)$ is seen as a promising mechanism for tackling

*Correspondence: Dr. Lasse Loft e-mail: lasse.loft@zalf.de Supplementary material can be found online at http://dx.doi.org/ $10.1017 /$ S0376892916000412 the drivers of deforestation and degradation in order to reduce emissions from the forestry sector and to support good forest governance (e.g. Arhin 2014). After a decade of negotiations, the framework for a REDD+ mechanism was finally completed in 2015 (at the 42nd session of Subsidiary Body for Scientific and Technological Advice). It is now a prominent mechanism in the Paris Agreement (see Article 5 ), which was reached in the scope of COP 21. With the financial commitments to the Paris Agreement finalized, the attention of national policy makers, researchers and practitioners can now focus on the full implementation of policies and measures (PAMs) and the safeguards and benefitsharing mechanisms (BSMs) that will be needed (Ravikumar et al. 2015). However, until now, most countries have not managed to properly address the drivers of deforestation and forest degradation. REDD+ implementation is in danger of being lost in the current policies dominated by business-asusual (BAU) interests (Brockhaus et al. 2014a). Due to the complex design and implementation processes of REDD+ PAMs at national and subnational levels, policy makers face severe risks and challenges when aiming to put into effect the objectives of sustainable emissions reductions and the provision of social and environmental side-objectives simultaneously (Harvey et al. 2010; Huettner 2012; Arhin 2014). These challenges are multifaceted and occur at different levels. They therefore affect different stakeholders within national REDD+ architectures.

According to Wertz-Kannounikoff and Angelsen (2009), core elements of the REDD+ architecture (Fig. 1) include a set of international institutions, such as global readiness funds and international carbon markets. These international institutions provide incentives for national and subnational institutions, such as governments or separate REDD+ (trust) funds outside of government administrations, to support readiness activities, to move towards advanced readiness and, finally, to move towards a full implementation of emissions reductions (Vatn \& Vedeld 2011). National institutions in turn implement PAMs, performance-based payment schemes and subnational activities to put into practice a set of REDD+ objectives. REDD+ objectives are broadly defined at the level of the international institutions and refined

This is an Open Access article, distributed under the terms of the Creative Commons Attribution licence (http://creativecommons.org/licenses/by/4.0/), which permits unrestricted re-use, distribution, and reproduction in any medium, provided the original work is properly cited. 


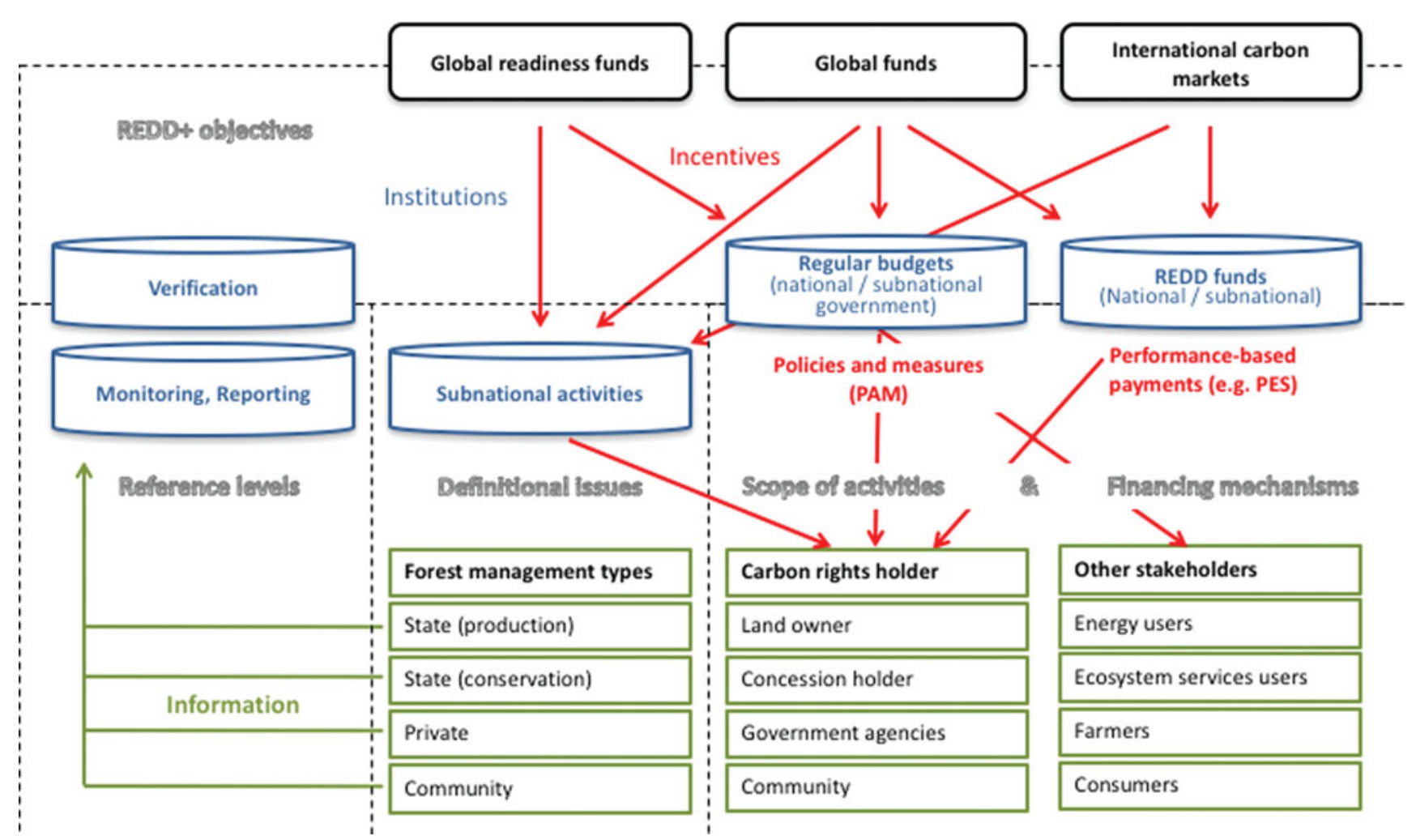

Figure 1 REDD+ architecture (adapted from Wertz-Kanounnikoff \& Angelsen 2009).

and adapted at national and subnational levels (Pham et al. 2013). Depending on the REDD+ objectives, PAMs, performance-based payments and subnational activities can variably target stakeholders, such as land and forest owners and managers. Furthermore, national REDD+ architectures require monitoring, reporting and verification (MRV) systems that deliver information on the achievement of reduced emissions necessary for triggering results-based payments (Herold et al. 2012). In addition to information on changes in carbon stored in forests, other information needs include those of the provision of payments in performance-based mechanisms and co-benefits (i.e. biodiversity and ecosystem services provision and changes in policy and governance) (Vatn \& Vedeld 2011). Both MRV systems and the distribution of REDD+ incentives can be institutionalized within government bodies and/or provided by independent (third-party) validation.

The complex structure of the REDD+ architecture also means that there are different risks involved in its implementation. It is important to understand the policies and governance factors causing these risks. Earlier publications have focused on hypothetical risks for socioeconomic and environmental co-benefits of REDD+ implementation (Harvey et al. 2010; Huettner et al. 2012). More recent publications assess specific elements of national REDD+ architectures, such as MRV (Ochieng et al. 2016) or BSMs (Dunlop \& Corbera 2016). However, there is little research that builds on actual in-country evidence to assess the range of political economic governance risks of national REDD+ implementation on a global scale.

The aim of this paper is to identify, assess and categorize major governance risks of national REDD+ implementation based on actual in-country experiences and to provide insights into how and why they occur and whom they potentially affect. This will allow policy makers to take mitigating or adaptive steps towards a more informed design and implementation of national REDD+ systems, making them more effective and equitable. We draw largely on data from the Center for International Forestry Research's (CIFOR) Global Comparative Study on REDD+ (GCS) in order to conduct a qualitative risks assessment in 13 countries that currently implement national REDD+ policies: Bolivia, Brazil, Burkina Faso, Cameroon, Democratic Republic of the Congo (DRC), Indonesia, Lao People's Democratic Republic (PDR), Mozambique, Nepal, Papua New Guinea (PNG), Peru, Tanzania and Vietnam. To allow for a systematic crosscountry comparison, we present and discuss the risks of the national REDD+ policy implementation along the stages of an ideal type of policy process (e.g. Fischer et al. 2007). The results section first presents risks in REDD+ policy formulation (i.e. trade-offs between objectives). Second, the policy design process highlights the risks of MRV and access to and distribution of finance. Third, the implementation phase covers the risks of illegitimate decision-making processes, 
Table 1 Country profiles included in this study.

\begin{tabular}{lll}
\hline \hline Country & World region & Reference \\
\hline Bolivia & Latin America & Müller et al. $(2014)$ \\
Brazil & Latin America & May et al. $(2011)$ \\
Burkina Faso & Sub-Sahara Africa & Kambire et al. $(2015)$ \\
Cameroon & Sub-Sahara Africa & Dkamela (2011) \\
Democratic Republic of the Congo & Sub-Sahara Africa & Mpoyi et al. $(2013)$ \\
Indonesia & Asia & Indrarto et al. $(2012)$ \\
Lao People's Democratic Republic & Asia & Lestrelin et al. $(2013)$ \\
Mozambique & Sub-Sahara Africa & Sitoe et al. $(2012)$ \\
Nepal & Asia & Paudel et al. $(2013)$ \\
Papua New Guinea & Oceania & Babon and Gowae (2013) \\
Peru & Latin America & Piu and Menton $(2014)$ \\
Tanzania & Sub-Sahara Africa & Kweka et al. (2015) \\
Vietnam & Asia & Pham et al. $(2012)$ \\
\hline \hline
\end{tabular}

risks of powerful elites securing rights to benefits and challenges of multilevel governance. We categorize these risks in our discussion section and close the paper with ideas on how countries could address and safeguard these shortcomings in the implementation of REDD+.

\section{METHODS}

This paper synthesizes findings presented in 'country profiles' that have been developed and updated since 2009 as part of the GCS (Brockhaus et al. 2012). Countries within the GCS were selected based on their early engagement with REDD+ and their engagement with different multilateral programmes, such as the World Bank's Forest Carbon Partnership Facility (FCPF) and Forest Investment Program (FIP), or large bilateral REDD+ programmes. Furthermore, attention was paid to geographical distribution and countries selected from Latin America, Sub-Sahara Africa, Asia and Oceania. Each country profile contains an in-depth description of the drivers of deforestation, an analysis of the political-economic and institutional contexts within which REDD+ is emerging, the policy options for REDD+ under discussion and an overview of the policy dynamics shaping the key issues and challenges in the country. CIFOR and its in-country partners employed extensive literature reviews, expert interviews and consultation workshops as the main methods for gathering information. The country profiles were produced following standard guidelines in order to support comparability across countries (Brockhaus et al. 2012).

All of the 13 country profiles included in this synthesis paper were either available as final drafts or already published as CIFOR Occasional Papers (Table 1). To complement and update the country profile data, we reviewed REDD+related policy documents and donor and government reports. We also included additional scientific literature in our analysis.

Our analysis follows a hybrid approach of deductive and inductive thematic analysis. Thematic analysis can be defined as a "form of pattern recognition within the data, where emerging themes become the categories for analysis" (Fereday \& Muir-Cochrane 2006: 82). We first conducted a review of journal articles that contained the keywords 'risks', 'safeguards' and 'REDD+ implementation'. Based on this review, we defined risks to REDD+ implementation as 'the potential failure to meet desired REDD+ outcomes' and identified a set of preliminary risk categories, following the deductive a priori template of codes approach established by Crabtree and Miller (1999). This set of risk categories formed a first set of codes for organizing our country profile data and for subsequent interpretation (i.e. a data-driven inductive approach) (Boyatzis 1998) (Table S1; available online).

We then analysed the content of the country profiles following their standardized report structure (Brockhaus et al. 2012), where each section and subsection heading became a code for our exploration of risks. For each section, two members of the team of authors undertook a comprehensive step-by-step analysis that included interpreting and summarizing the data and then clustering and matching the data segments with the preliminary codes. The preliminary codes guided, but did not confine, the analysis at this stage. During the coding of country profiles, inductive codes were assigned to segments of the data that described a new theme observed in the text. At the final stage, six politicaleconomic core risk themes were identified based on the data from the country profiles by the team of authors and through stakeholder discussions in an iterative process (Table 2). Due to the dynamic processes in the countries studied, in-country experts were consulted during the writing process in order to verify our findings.

\section{RESULTS}

Risks in REDD+ policy formulation: trade-offs between objectives

Based upon internationally defined REDD+ goals, candidate countries started a process of national and subnational policy 
Table 2 Political-economic risks for REDD+ implementation along the stages of an ideal type of policy process.

\begin{tabular}{|c|c|c|c|}
\hline $\begin{array}{l}\text { Stage in the } \\
\text { policy process }\end{array}$ & $\begin{array}{l}\text { Feature of REDD+ } \\
\text { implementation }\end{array}$ & Effects & Risks \\
\hline Policy formulation & $\begin{array}{l}\text { Definition of the } \\
\text { objectives of REDD+ }\end{array}$ & $\begin{array}{l}\text { Determines scope of activities and } \\
\text { targeted stakeholders }\end{array}$ & $\begin{array}{l}\text { Overlapping policies, contradicting } \\
\text { measures, inequitable distribution of } \\
\text { benefits and burdens }\end{array}$ \\
\hline \multirow[t]{2}{*}{ Policy design } & $\begin{array}{l}\text { Reference emissions levels } \\
\text { and monitoring }\end{array}$ & $\begin{array}{l}\text { Determines emissions reductions, } \\
\text { impacts potentially targeted } \\
\text { stakeholders }\end{array}$ & $\begin{array}{l}\text { Inaccurate setting of reference levels and } \\
\text { monitoring may create artificial } \\
\text { emissions reductions and market } \\
\text { distortion due to asymmetric } \\
\text { information }\end{array}$ \\
\hline & $\begin{array}{l}\text { Finance and benefit } \\
\text { sharing }\end{array}$ & $\begin{array}{l}\text { Determines eligible benefitting } \\
\text { stakeholders, sets incentives for } \\
\text { land use change }\end{array}$ & $\begin{array}{l}\text { Insufficient funding and lack of } \\
\text { institutional context factors, such as } \\
\text { property rights, management and } \\
\text { monitoring capacity and } \\
\text { non-transparent financial flows may } \\
\text { lead to elite capture and funds not } \\
\text { reaching targeted stakeholders }\end{array}$ \\
\hline \multirow[t]{3}{*}{$\begin{array}{l}\text { Policy } \\
\text { implementation }\end{array}$} & $\begin{array}{l}\text { Stakeholder } \\
\text { representation }\end{array}$ & $\begin{array}{l}\text { Determines procedural equity and } \\
\text { legitimacy of implementation }\end{array}$ & $\begin{array}{l}\text { Domination by powerful groups, elite } \\
\text { capture of benefits, corruption } \\
\text { REDD+ policies and measures perceived } \\
\text { as inequitable and illegitimate, may lead } \\
\text { to opposition to implementation }\end{array}$ \\
\hline & Carbon and tenure rights & $\begin{array}{l}\text { Determines land use obligations and } \\
\text { rights to benefits streams }\end{array}$ & $\begin{array}{l}\text { Lack of legal clarity may lead to high } \\
\text { transaction costs and high potential for } \\
\text { fraud in market-like mechanisms } \\
\text { Conflicts between customary and } \\
\text { statutory rights } \\
\text { Elite capture, exclusion of landless poor }\end{array}$ \\
\hline & Multilevel governance & $\begin{array}{l}\text { Determines ownership of local } \\
\text { governments, non-state agencies } \\
\text { and local communities over forest } \\
\text { policy }\end{array}$ & $\begin{array}{l}\text { Lack of capacity for implementation at } \\
\text { subnational and local levels } \\
\text { Opaque bureaucratic processes at } \\
\text { multiple levels that facilitate elite } \\
\text { capture and corruption } \\
\text { Lack of information sharing between } \\
\text { governance levels }\end{array}$ \\
\hline
\end{tabular}

formulation and adoption. Except for Brazil and Bolivia, all of the countries studied have produced at least draft Readiness Preparation Proposals (R-PP) for the World Bank's FCPF. The R-PP is a framework for a country to set up a clear plan, budget and schedule in order to undertake REDD+ activities. In addition, the majority of the 13 countries analysed in this paper are in the final stages of developing national REDD+ strategies: Brazil, DRC, Mozambique, Tanzania, Indonesia, Nepal and Vietnam (Table S2). These strategies include the definition of environmental and socioeconomic co-objectives and the design of REDD+ architectures that correspond with the national context and priorities.

However, as Luttrell et al. (2013) have shown, there is a potential for trade-offs between the primary goal of efficient and effective emissions reductions and the co-objectives. From our sample of 13 candidate countries, we can identify two types of risks associated with the definition of national and subnational REDD + objectives. First, REDD + objectives are often not clearly defined, which creates a risk of contradictory or overlapping policies and of ineffective implementation.
One example is the Tanzanian REDD+ strategy, which is closely integrated into national growth and development policies. Through this integration, the goals of REDD+ are being overshadowed by other well-funded donor initiatives that aim to develop both small- and large-scale commercial agriculture and may encourage expansion of agriculture into forests (Kweka et al. 2015).

Second, the definition of different REDD+ objectives influences the ways in which different stakeholders are affected. For example, are the objectives aimed at those responsible for most of the deforestation or those who have been managing natural forests sustainably for the past decades? The identification of stakeholders will inevitably create REDD+ benefit (and burden) sharing with differential socioeconomic impacts, consequently affecting the perceived equity and legitimacy of REDD+ implementation. Thus, a focus placed solely upon effective and efficient emissions reductions may lead to predominantly incentivizing largescale actors to reduce carbon emissions because, in many cases, such actors are the dominant drivers of deforestation. 
For example, in Vietnam, $85 \%$ of forest areas are managed by state-owned companies (Pham et al. 2012). In Brazil, largescale landowners account for about $80 \%$ of all deforestation (Börner et al. 2010). A performance-based payment scheme that includes and allocates most internationally generated REDD+ benefits to these actors could thus by perceived as highly unfair and illegitimate.

A focus on effectiveness in emissions reductions will prevent the sharing of benefits with those that have been good forest stewards, as there is little or no additionality from the BAU activities of low-emitting actors. However, completely neglecting their efforts in forest conservation might itself create a perverse incentive for actors to carry out emitting activities, as only then would they be eligible for REDD+ benefits. For example, under the national Payment for Forest Ecosystem Services (PFES) implementation in Vietnam, those who have had forests for the last 20 years are not eligible to receive Payment of Ecosystem Services (PES) due to the lack of additionality. As a result, instead of protecting forests, these groups are now the main actors behind deforestation and forest degradation (Pham et al. 2014).

A focus on targeting holders of legal rights to forest or land use, as a requirement for efficient market-based distribution mechanisms, may lead to the exclusion of the poorest people from receiving any benefits because most small-scale forest users do not hold formal rights over the land. For example, in Nepal, Vietnam and Laos PDR, the vulnerable and poor often do not have formal land titles and therefore are not eligible to receive any payment from forest protection (Pham et al. 2012; Lestrelin et al. 2013; Paudel et al. 2013).

A pro-poor focus may serve to counter inherent contextual inequity and strengthen the moral and political legitimacy of REDD+, but this might lead to a low efficiency of emissions reductions. Poverty reduction is an explicit objective in the strategies of DRC, Burkina Faso, Mozambique and Vietnam (Pham et al. 2012; Sitoe et al. 2012; Mpoyi et al. 2013; Kambine et al. 2015).

\section{Risks in designing REDD+ architectures}

Policy formulation must involve identifying a set of policy alternatives. The core elements of any REDD+ architecture for which such alternatives are being discussed include information generation through MRV systems and the distribution of benefits.

\section{$M R V$ : risks of artificial baseline setting and asymmetric information}

The availability of information on generated emissions reductions is essential for any REDD+ system. A precondition for measuring emissions reductions is that reference levels (RLs) are defined. These RLs are the benchmarks for assessing a country's performance in implementing REDD+ activities. Angelsen et al. (2011: 2) define RLs as the (hypothetical) BAU scenario of future emissions from deforestation and degradation "as well as the amount of removals from sustainable management of forests and enhancement of forest carbon stocks" in the absence of REDD+ activities. If RLs are set inaccurately or are inflated, the additionality of REDD+ activities may be overestimated. This poses the risk of generating artificial emissions reductions by rewarding de facto BAU behaviour. If RLs are set too high, countries may face the risk of losing appropriate compensation for their upfront investments (or inputs) in order to achieve the emissions reduction. As Angelsen (2016: 9), referring to an unknown, points out, "a reference level is a benchmark set so low that success is guaranteed." This indicates the risk that setting a (desired) RL is more a result of political negotiations than an attempt at accurate measuring.

The quality of data is key to any approach aimed at managing the politics of numbers, as outlined above in the RL setting. Even though there have been major improvements in remote sensing and data are accessible through platforms like the Global Forest Watch, the availability of (accurate) data is still limited in most countries (Herold et al. 2012; Ochieng et al. 2016). Remote sensing provides useful data, but reliable measurements also require field-based data collection, or 'ground truthing', in order to verify the analysis. Assessing the status and development of national administrative capacities to implement MRV, we find that most countries have indeed made progress. However, administrative capacity for MRV was still considered low in PNG, Nepal, Laos PDR and Mozambique, moderate in Burkina Faso and Cameroon, high in Bolivia, Peru and Vietnam and only very high in Indonesia, Brazil and DRC (Ochieng et al. 2016).

Furthermore, differences in the collection of data on land and in forests are problematic. In Vietnam, for example, discrepancies in forestry data were found when comparing the country's two separate databases on land classification and administration. The first database, maintained by the Ministry of Natural Resources and Environment, contains information on land management, including land area and land use planning. The second database, managed by the Ministry of Agriculture and Rural Development, defines categories of forest and forestland and contains data on the extent of forest coverage (Pham et al. 2012). The existence of two land use classification systems complicates monitoring and reporting efforts: assessments will be based on changes in forest cover over time, whereas REDD+ benefit sharing depends on land use registration data. Likewise, in Indonesia, discrepancies in the data collected on forests are attributable to differences in the definition of forest, forest classifications and data analysis methods, despite efforts to harmonize these through a one-map policy (Indrarto et al. 2012). In DRC, primary data sources are difficult to identify because there is very little centralization of statistics and very few people are trained in this field (Mpoyi et al. 2013). Similarly, Laos PDR lacks reliable carbon data at the national level (Lestrelin et al. 2013). Therefore, it is not surprising that amongst all of the countries studied, the only country that submitted a (historical) RL to the UN Framework Convention on Climate Change (UNFCCC) in 2014 was Brazil. 
In addition, the mapping of forests and lands could also disrupt illegal logging and land grabbing activities, which may have strong political-economic connections, thus leading to stalled MRV processes. Building capacities for forest monitoring and carbon accounting is thus not simply a technical process, but also a political challenge for governmental forest management agencies, and could be undermined by bureaucratic resistance on the part of state forestry institutions (Global Witness 2011). For example, the delay in the creation of a MRV institution in Indonesia was attributed by many informants to the resistance from existing sectoral ministries that would see some of their functions transferred to a new institution (NORAD 2013).

\section{Accessing REDD+ finance: risks in meeting and measuring 'performance'}

Funding for REDD+ PAMs, pilot projects and programmes has come from different sources, including voluntary contributions and bilateral funds (e.g. those provided by Norway to Indonesia and Brazil) (May et al. 2011; Indrarto et al. 2012), as well as multilateral funds like the World Bank's FCPF and UN-REDD. Ultimately, these bilateral and multilateral funding sources will be bundled together in an international funding mechanism under the UNFCCC, such as the Green Climate Fund. However, currently, insufficient or unreliable international financing for REDD+ has been cited by REDD+ countries as one of the major obstacles to the implementation of REDD+ (Sunderlin et al. 2014).

A comparative policy study of the 13 countries seems to confirm that REDD+ financing is one factor that has enabled policy reforms; countries with access to performance-based funding (Brazil and Indonesia) were found to have advanced more quickly in implementing policy reforms than the others when this access to performance-based funding was combined with national ownership in the REDD+ process (Brockhaus et al. 2016). However, the same study also found that the implementation of REDD+ PAMs was generally a very slow and tedious process.

Even if it is available, accessing performance-based funding is not an easy matter. Implementing REDD+ PAMs in order to counter deforestation drivers and BAU practices also comes with risks (Brockhaus et al. 2014a). One of them is the increased resistance of powerful BAU interests and the fear of harm to a government's economic interests (e.g. tax revenues). Secondly, development aspirations that build on forest exploitation and conversion to other uses than sustainable forest management (e.g. agriculture) can be seen to be threatened, especially if the alternative development policies are not clearly mapped out. The vulnerability to these risks and difficulty in policy progress suggest that the identification of unambiguous policy performance indicators would be a complex process (Wong et al. 2016) and could hamper access to performance-based finance.

\section{REDD+ BSMs: risks to equity from inadequate design}

Both institutional structures and policy instruments for distributing REDD+ benefits are key elements in the design of the REDD+ architecture (Luttrell et al. 2013). Different funding and distribution mechanisms work better in some contexts than others, depending on the governance and enabling factors. If relevant factors are not in place, the REDD+ BSMs may fail to provide sufficient incentives to motivate policy reforms and changes in behaviour. This would thus place the national REDD+ policy at risk of being ineffective, inefficient and inequitable.

Most of the countries analysed have proposed mixed approaches to the REDD+ BSMs in order to obtain, administer and allocate financial resources directly for implementation agencies and target stakeholders (Table S3). These include (Pham et al. 2013):

- A fund-based approach (Brazil, Burkina Faso, Cameroon, DRC, Tanzania, Indonesia and Vietnam). Although all countries differ in their preferences regarding the fundbased model, they face common risks in the establishment and operation of these funds. The potentially large amount of payments channelled to the relevant funds provokes organizational competitions and conflicts over power and interests and, as in the cases of Nepal, Indonesia and Vietnam, between the Ministries of Finance and Forestry (Indrarto et al. 2012; Pham et al. 2012; Paudel et al. 2013). In addition, while discussions in these countries generally focus on how these funds should be managed and by whom, the central concepts of how they should be used and how benefits should be shared remain abstract, potentially leading to risks of inequity and ineffectiveness.

- Decentralized, nested approaches in which the national government distributes REDD+ benefits to subnational jurisdictions based on their emissions reductions performance (Brazil and Peru) (Loft et al. 2015). This approach would require a clear devolution of rights and a multilevel governance system in order to be effective.

- Building on existing systems. For example, Cameroon is looking to establish a BSM based on its forest and wildlife revenue redistribution mechanism (Dkamela et al. 2011). Meanwhile, Nepal has focused on its existing protected areas and community forestry systems (Paudel et al. 2013), and Vietnam (Pham et al. 2012) will most likely establish a BSM that is similar to its national PFES programme. While building on existing systems can be cost efficient, it does bring forth the risk of reinforcing any systemic regulatory, procedural and/or governance flaws inherent in the system. For example, the lack of participation and inclusiveness in decision-making processes around forest revenue redistribution policies in Cameroon has reinforced the historical marginalization of women and forest minorities such as the Pygmy groups (Dkamela et al. 2014; Assembe-Mvondo et al. 2015).

Several countries have not yet defined any such approach (Bolivia, Laos PDR, Mozambique and PNG). Not providing 
clear signals on a BSM risks generating confusion and misinterpretation while disincentivizing performance in reducing deforestation and forest degradation.

\section{Risks to REDD+ implementation}

In addition to setting the risks in policy objectives and elementary design principles of a national REDD+ architecture, the potential risks of the implementation phase need to be taken into account. Different contextual institutional factors, such as clearly defined property rights, inclusive multilevel governance structures for collective action and institutional and organizational management capacities, will affect the implementation of REDD+ (Börner \& Vosti 2013). If these contextual factors are not sufficiently taken into account when implementing a particular REDD+ architecture, PAMs face the risk of being ineffective.

\section{Risks of illegitimate decision-making processes and policy implementation}

The design and implementation of public policies is a political process that is often obstructed by the resistance of domestic actors (Fisher et al. 2007). The effective, efficient and equitable design and implementation of PAMs is highly contingent on the legitimization of REDD+ policies (Luttrell et al. 2013), which occurs through participation in decision making at all phases in the political process. Analyses by Kengoum et al. $(2011,2014)$ and Dkamela et al. (2014) for DRC and Cameroon highlight that participation in agenda setting is very much limited to a few state and international actors, whereas in Brazil and Indonesia, studies have detected higher levels of active engagement by actors from civil society (Gebara et al. 2014; Cronin et al. 2016).

Evidence from the country profiles strongly indicates that decision making and discussions on REDD+ are dominated by powerful stakeholders like government agencies, private sector alliances and donors, with limited participation of vulnerable and marginalized groups, such as customary users and indigenous people (Babon \& Gowae 2013; Indrarto et al. 2012; Mpoyi et al. 2013; Müller et al. 2014; Pham et al. 2014). For instance, REDD+ policies in Nepal are largely shaped by interactions among a triad of forest government agencies, international actors and powerful civil society organizations (CSOs), whereas community organisations that represent weaker actors of society are only marginally involved and have little influence on REDD+ policy making (Paudel et al. 2013). In Cameroon, international actors are dominant in controlling and facilitating information flows between organizations, while state actors and CSOs are less involved (Dkamela et al. 2014). Meanwhile, the consultation process for REDD+ in Laos PDR and Peru is still in its early stages. Free prior informed consent has not been well implemented in these countries, hence increasing the risk of excluding local people (Lestrelin et al. 2013; Piu \& Menton 2013). Consequently, in most countries, the REDD+ design and implementation process is failing to provide a platform for non-state actors to have a voice in decision making (Kengoum 2011; May et al. 2011; Pham et al. 2012; Babon \& Gowae 2013; Paudel et al. 2013; Piu \& Menton 2013). This may create biases in REDD+ design and lead to elite capture of benefits. For example, in Vietnam's national PFES programme, marginal and vulnerable groups were excluded from planning and decision-making processes as the programme was being designed. Now, in the programme's implementation phase, these groups have limited capacities and opportunities to access these benefits, which are mostly captured by powerful groups, such as state enterprises and mass organizations (Pham et al. 2013). The collusions between these powerful groups that are drivers of deforestation and forest degradation and complicit political institutions can be a strong force in resisting change in BAU practices (e.g. in Lao PDR and PNG) (Babon \& Gowae 2013; Lestrelin et al. 2013). Yet it is precisely these changes that are necessary for the implementation of a REDD+ approach that successfully achieves its objectives (Brockhaus et al. 2014b).

A particular risk is posed by increasing levels of corruption in the areas of land use planning, land and natural resource tenure, allocation of carbon rights, setting reference emission levels and the design of BSMs (Thorpe \& Ogle 2011). Dermawan et al. (2011) conclude that corruption in the REDD+ policy arena in Indonesia is likely to undermine efforts to reduce forest conversion, as land classification is being manipulated by illegally declaring intact forests as degraded land so that large areas can then be 'legally' destroyed for commercial purposes. Similarly, Pham et al. (2012) and Barr et al. (2010) observe that the misuse of reforestation programme budgets in Vietnam and Indonesia is another result of corruption.

\section{Carbon and tenure rights: risks of powerful elites securing rights} to benefits

If REDD+ is designed as a performance-based mechanism at the national level, it is important to ensure that those who are responsible for reducing emissions reductions have the longterm rights to do so. Provided that these rights are secured, relevant stakeholders can be rewarded if they successfully reduce emissions, but can also be held responsible in case of failure (Sunderlin et al. 2014; Loft et al. 2015). One option for the manifestation of such a responsibility could lie in the definition and clarification of 'carbon rights' (Loft et al. 2015). Our findings reveal that although the legal clarification of carbon rights is perceived as a pressing issue in many REDD+ candidate countries, it has nonetheless progressed quite slowly: Vietnam and Peru have defined carbon rights to varying degrees in their national PES laws. In Indonesia, multiple laws and decrees for the provision of the ecosystem service of carbon sequestration and storage do exist, but doubts remain as to their validity and enforceability. In Brazil, some federal states in the Amazon have adopted carbon rights legislation. Meanwhile, many countries, such as Cameroon, have not advanced any explicit legal clarification of carbon rights at all (Dkamela 2011; Loft et al. 2015). 
The lack of legal clarity poses several risks. Different interpretations of the law may lead to competing claims among stakeholders who hold different tenure rights over forest and land resources. In Cameroon, for example, the majority legal opinion concerning carbon ownership is that it will follow the same legal status as other natural resources (i.e. following the ownership of land). However, there is no explicit legislation or respective jurisdiction by the courts on this matter, so uncertainty remains. Some authors argue that a carbon credit could be categorized as an intangible asset (see Dkamela 2011) and take the form of a monetary asset representing the result of an action. Accordingly, ownership of carbon credits would be granted to forest actors who prove that they support that action. This claim would not necessarily be based on land tenure, but could also include ancestral rights, operating rights, use rights or capital investment (Loft et al. 2015). This can result in higher transaction costs for REDD+ initiatives, as without legal clarity, project developers must act on a case-by-case basis. Wieland (2013) cites several cases from Peru, among them a Conservation International (CI) REDD+ project, in which CI was seeking an explicit clause in the management agreement with the National Protected Areas Entity to clearly transfer all carbon rights. It has been reported that not having a specific legal framework has increased the transaction costs of CI's project substantially. Furthermore, based on experiences with clean development mechanism projects, it has been speculated that with a separation of carbon rights from land ownership, it could be easy to conceal, and equally difficult to monitor and control, forest carbon trade fraud (Global Witness 2011). As highlighted by research on tenure and benefit sharing, there is a high risk of unlawful issuance of use rights, especially in countries with weak governance and high corruption levels, such as Cameroon or Indonesia (Dkamela 2011; Indrato et al. 2012).

Most countries, such as Peru, Brazil, Cameroon, Vietnam and Indonesia, tie the right to benefit from carbon sequestration and storage to land rights (Loft et al. 2015). As a result, they face common tenure rights problems (Table S4). Particularly in Indonesia, Vietnam, Cameroon, Burkina Faso and Tanzania, we can observe a lack of clarity about resource ownership, overlapping claims and conflicts between customary and statutory rights. Bolivia, Mozambique and Laos PDR provide examples of conflicting land use decisions across levels and state institutions, a lack of exclusion rights and/or ability to exclude and weak law enforcement, monitoring and application of sanctions (see Supplemental Material for country details; available online). The risks related to these tenure problems constitute ineffective and inequitable outcomes (Larson et al. 2013).

\section{Challenges of multilevel governance}

REDD + design and implementation faces several challenges due to its multilevel governance characteristics. An effective coordination of actors is necessary, both vertically (i.e. through a hierarchy of jurisdictions or central bodies) and horizontally (i.e. via cross-sector coordination between departments or state and non-state actors) (Korhonen-Kurki et al. 2013).

Vertical coordination deficits and conflicts of interests amongst national, regional and local governance levels are widely found in all countries. For example, Brazil has, until recently, conducted its efforts to combat deforestation by following a vertical approach. Coordination has been centralized and applied in a top-down manner, partly due to a policy vacuum at the federal level (May et al. 2011). Conflicts between national and local governments are often rooted in the lack of clarity of the rights of local governments to exercise their discretion regarding the implementation of broader REDD+ interventions (Korhonen-Kurki et al. 2013). In Nepal, for example, the centralization of authoritative and control rights is regarded as a cause of the weak ownership of local governments, non-state agencies and local communities over forest policy and governance (Paudel et al. 2013). In Indonesia, we observe a lack of coordination between the central government and regional administrations, and latent conflicts and new disputes emerge due to unclear and changing division of authority (Ardiansyah et al. 2015). Local-level governments in PNG are often not aware that they have the authority to make laws pertaining to the local environment; they are also often confused about who has what power, and they lack the capacity to carry out their roles effectively (Babon \& Gowae 2013). Similar, in Vietnam, payment flows of the national PFES scheme are considerably constrained by limited financial and human resources at the subnational (provincial) level (Pham et al. 2012).

We find that weak horizontal coordination amongst government agencies and national actors is a major risk factor for the effective implementation of REDD + in all of the countries studied. There is often a lack of leadership by the central government and coordination among ministries (e.g. Indonesia, Vietnam, Bolivia, Cameroon, PNG and Laos PDR) (Dkamela 2011; Indrarto et al. 2012; Lestrelin et al. 2012; Pham et al. 2012; Babon \& Gowae 2013; Müller et al. 2014). For example, in Laos PDR, the transfer of responsibility for the conservation and protection of forests from the Ministry of Agriculture and Forestry to the Ministry of Natural Resources and Environment has led to unstable power relations, unclear mandates and poor coordination between these two key ministries (Lestrelin et al. 2012). Similarly, in Indonesia, there was a long struggle over responsibilities for revenue sharing arrangements for REDD+ between the Ministry of Finance and the Ministry of Forestry, which are still unclear (Loft et al. 2015). In addition to a lack of ministerial coordination and cooperation in Cameroon, the large number of (mostly non-functioning) inter- and intra-sectoral coordination committees and the institutional instability due to ministerial reorganizations very frequently undermine coordination processes (Dkamela 2011). Similar reorganization challenges were observed in Nepal, DRC and Indonesia (Indrarto et al. 2012; Mpoyi 
Table 3 Design and context risks.

\begin{tabular}{|c|c|c|}
\hline Identified risk categories & Risks related to $R E D D+$ design & Risks related to context \\
\hline $\begin{array}{l}\text { Formulation of REDD+ } \\
\text { objectives }\end{array}$ & $\begin{array}{l}\text { Perceived inequity and illegitimacy of } \\
\text { cost and burden sharing }\end{array}$ & - \\
\hline $\begin{array}{l}\text { Monitoring, reporting and } \\
\text { verification }\end{array}$ & - & $\begin{array}{l}\text { Generation of artificial emissions reductions } \\
\text { Differences in data collection and discrepancies in forest data }\end{array}$ \\
\hline Accessing REDD+ finance & - & $\begin{array}{l}\text { Bureaucratic resistance on part of state forestry institutions } \\
\text { Increased resistance of powerful business-as-usual interests }\end{array}$ \\
\hline $\begin{array}{l}\text { REDD+ benefit-sharing } \\
\text { mechanisms }\end{array}$ & $\begin{array}{l}\text { Funds-based approaches face the risks } \\
\text { of organizational competitions and } \\
\text { conflicts over power and interests } \\
\text { Building on existing structures risks } \\
\text { reinforcing any systemic regulatory, } \\
\text { procedural and/or governance flaws } \\
\text { inherent in the system } \\
\text { Not providing clear signals on a } \\
\text { benefit-sharing approach risks } \\
\text { generating confusion and } \\
\text { misinterpretation while } \\
\text { disincentivizing performance to } \\
\text { reduce deforestation }\end{array}$ & $\begin{array}{l}\text { Decentralized nested approaches risk ineffectiveness if they } \\
\text { lack a clear devolution of rights and a multilevel governance } \\
\text { system }\end{array}$ \\
\hline $\begin{array}{l}\text { Decision-making processes and } \\
\text { policy implementation }\end{array}$ & $\begin{array}{l}\text { Domination of decision-making } \\
\text { processes and discussion by powerful } \\
\text { stakeholders }\end{array}$ & $\begin{array}{l}\text { Domination of decision-making processes and discussion by } \\
\text { powerful stakeholders } \\
\text { Corruption in public administration }\end{array}$ \\
\hline Carbon and tenure rights & - & $\begin{array}{l}\text { Lack of legal clarity on carbon rights may lead to competing } \\
\text { claims } \\
\text { Common tenure rights problems, such as a lack of clarity } \\
\text { about resource ownership, overlapping claims and conflicts } \\
\text { between customary and statutory rights }\end{array}$ \\
\hline Multilevel governance & $\begin{array}{l}\text { Capacity constraints at subnational } \\
\text { governance levels }\end{array}$ & $\begin{array}{l}\text { Weak horizontal cross-sector coordination between } \\
\text { departments or state and non-state actors }\end{array}$ \\
\hline
\end{tabular}

et al. 2013; Paudel et al. 2013). Furthermore, we find that intersectoral policy coordination still poses challenges for REDD+ implementation. For example, in Brazil, sectoral support of expanded agribusiness, mining, transportation and energy infrastructure still contradicts the vision of REDD+ (May et al. 2011). The implementation of the Interministerial Working Group - Action Plan or Prevention and Control of Deforestation in the Legal Amazon has yielded mixed results, demonstrating both the potential for the federal government to more effectively address deforestation dynamics on the one hand and the enormous problems with regards to institutional coordination on the other. What is more, coordination between and amongst Brazilian states in order to guarantee the effectiveness of REDD+ actions is relatively limited (May et al. 2011).

The lack of a functioning multilevel governance system thus undermines the success of REDD+ implementation. Although REDD+ has largely been seen as creating incentives to induce behaviour change at a local level, it can equally contribute towards catalysing change in multilevel governance. Mitigating these risks within in a multilevel governance structure requires improved coordination among actors, better law enforcement, clear guidance for and monitoring of financial flows, improved information exchange and stronger capacity of the actors involved.

\section{DISCUSSION}

An important element of policy analysis is to understand the potential risks and how these can be prevented. Evidencebased analysis helps reduce the uncertainty attached to policy design and implementation as far as possible (Huettner 2012). As our paper has highlighted, risks related to REDD+ are multifaceted and occur at multiple scales. Some of the risks are related to how REDD+ PAMs are designed, and could thus be managed through reflexive policy learning and adaptive implementation. Other risks are related to a country's unique political and economic context, which has to be carefully considered when thinking about specific national REDD+ designs (Table 3). There may be room for mitigation, but often these contextual risks are beyond the scope of control.

Some of the risks are obviously linked to both design and context; for example, while REDD+ can be designed to provide adequate avenues for inclusive participation and decision making, contextual factors such as state control over information, power relations, hierarchy dynamics and 
sociocultural norms can easily dominate. Many of these risks can be mitigated and managed only by improved coordination among actors, better law enforcement, clear guidance for and monitoring of financial flows, improved information exchange and stronger capacity of the actors involved. Whether REDD+ can catalyse these changes will depend in part on how the costs and benefits of REDD+ are shared and whether the incentives through results-based payments are sufficient to induce change in entrenched behaviour and politics at all levels of government. The ongoing development of REDD+ safeguards would benefit from a careful review of these risks, with specific criteria and indicators identified in order to support their effective monitoring and mitigation.

Nevertheless, some progress has been made (Seymour \& Angelsen 2012): the REDD+ debate has, in some countries, stimulated a review of existing legal frameworks in order to clarify tenure and rights over carbon; investments in MRV systems could enable performance-based benefit sharing; new coalitions are being formed in national policy arenas; and a new agency around the value of standing forests has emerged (Di Gregorio et al. 2013; Brockhaus et al. 2014a). All of these developments will contribute towards the creation of the necessary enabling conditions for the achievement of the effective, efficient and equitable design and implementation of REDD+ architectures. At the same time, it is obvious that there are trade-offs and conflicts between these 3Es and between alternative ideas of what REDD+ implementation should achieve. In order to properly manage such tradeoffs, the key objective a country wants to pursue through REDD+ would need to be clarified early on in the policy design process. This would safeguard the legitimacy of those that make decisions during the subsequent implementation processes.

Ultimately, for REDD+ PAMs to be effective, efficient and equitable, the design process should incorporate clear objectives at national and local levels, as well as a careful analysis of the options that are available and their potential impacts on different stakeholder groups in trying to achieve the multiple goals of reduced emissions, improved livelihoods and ecosystem services provisioning. A good understanding of the risks inherent in a country's contextual factors and how they might influence or be exacerbated by the design of a REDD+ policy or BSM is a necessary precursor to how REDD + can actually achieve its objectives.

\section{CONCLUSION}

We distinguish between two broad categories of risks: risks related to external context, which REDD+ design needs to take into account (but does not cause), and those related to the actual REDD+ mechanism, which can be avoided through design. One way for countries to address and safeguard against these shortcomings in the implementation of REDD+ is by employing a more systematic approach to classifying these risks and by understanding their impacts on different stakeholder groups, as well as their impacts on the achievement of specific objectives. REDD+ could be made part of a structured policy learning process. A possible approach to identifying and evaluating existing and potential risks and solutions is through multi-stakeholder forums, which can also further serve to enhance the credibility and legitimacy of the process (Luttrell \& Fripp 2015). Another possible avenue for addressing and monitoring these risks is by identifying relevant criteria and indicators in the REDD+ safeguards process (Brockhaus et al. 2014c), as these will be part of the reporting mechanism for access to REDD+ finance. Ultimately, whether and how countries are willing to address these risks and the deeply engrained BAU practices that they are related to will depend not only on REDD+ incentives alone, but also on ownership over the REDD+ process.

\section{CONFLICT OF INTEREST}

None.

\section{FINANCIAL SUPPORT}

This work is part of CIFOR's project 'Opportunities and challenges for implementing REDD+ benefit sharing mechanisms in developing countries', funded by the European Commission (grant number: DCIENV/2011/269520); the Norwegian Agency for Development Cooperation (NORAD); the Australian Agency for International Development; the UK Government of the Department for International Development (UKAID); and the CGIAR Research Program on Forests, Trees and Agroforestry (CRP-FTA), with financial support from the CGIAR Fund Donors.

\section{SUPPLEMENTARY MATERIAL}

To view supplementary material for this article, please visit http://dx.doi.org/10.1017/S0376892916000412

\section{References}

Angelsen, A., Boucher, D., Brown, S., Merckx, V., Streck, C. \& Zarin, D. (2011) Modalities for REDD+Reference Levels: Technical and Procedural Issues. Oslo, Norway: Meridian Institute.

Angelsen, A. (2016) REDD+ as results-based aid: general lessons and bilateral agreements of Norway. Reviem of Development Economics (online first, DOI: 10.1111/rode.12271).

Ardiansyah, F., Marthen, A.A. \& Amalia, N. (2015) Forest and LandUse Governance in a Decentralized Indonesia: A Legal and Policy Reviem. Bogor, Indonesia: CIFOR.

Arhin, A.A. (2014) Safeguards and dangerguards: a framework for unpacking the black box of safeguards for REDD+. Forest Policy and Economics 45: 24-31.

Assembe-Mvondo, S., Wong, G.Y., Loft, L. \& Tjajadi, J.S. (2015) Comparative Assessment of Forest Revenue Redistribution Mechanisms in Cameroon: Lessons for REDD+ Benefit Sharing. Bogor, Indonesia: CIFOR.

Babon, A. \& Gowae, G.Y. (2013) The Context of REDD+ in PNG: Drivers, Agents, and Institutions. Bogor, Indonesia: CIFOR. 
Barr, C., Dermawan, A., Purnomo, H. \& Komarudin, H. (2010) Financial Governance and Indonesia's Reforestation Fund during the Soeharto and post-Soeharto Periods, 1989-2009: A Political Economic Analysis of Lessons for REDD+. Bogor, Indonesia: CIFOR.

Börner, J., Wunder, S., Wertz-Kanounnikoff, S., Tito, M.R., Pereira, L. \& Nascimento, N. (2010) Direct conservation payments in the Brazilian Amazon: scope and equity implications. Ecological Economics 69: 1272-1282.

Börner, J. \& Vosti, S.A. (2013) Managing tropical forest ecosystem services: an overview of options. In: Governing the Provision of Ecosystem Services, eds. R. Muradian \& L. Rival, pp. 21-46. New York, NY, USA: Springer.

Boyatzis, R. (1998) Transforming Qualitative Information: Thematic Analysis and Code Development. Thousand Oaks, CA, USA: Sage.

Brockhaus, M., Di Gregorio, M. \& Wertz-Kanounnikoff, S. (2012) Guide for Country Profiles: Global Comparative Study on REDD (GCS-REDD) Component 1 on National REDD+ Policies and Processes. Bogor, Indonesia: CIFOR.

Brockhaus, M., Di Gregorio, M. \& Mardiah, S. (2014a) Governing the design of national REDD+: an analysis of the power of agency. Forest Policy and Economics 49: 23-33.

Brockhaus, M., Gregorio, M.D. \& Carmenta, R. (2014b) REDD+ policy networks: exploring actors and power structures in an emerging policy domain. Ecology and Society 19: 29.

Brockhaus, M., Wong, G., Luttrell, C., Loft, L., Pham, T.T., Duchelle, A.E., Assembe-Mvondo, S. \& Di Gregorio, M (2014c) Operationalizing safeguards in national REDD+ benefit sharing systems. REDD+ Safeguards Brief No. 2. Bogor, Indonesia: CIFOR.

Brockhaus, M., Korhonen-Kurki, K., Sehring, J., Di Gregorio, M., Assembe-Mvondo, S., Babon, A., Bekele, M., Gebara, M.F., Khatri, D.B., Kambire, H., Kengoum, F., Kweka, D., Menton, M., Moeliono, M., Paudel, N.S., Pham, T.T., Resosudarmo, I.A.P., Sitoe, A.A., Wunder, S. \& Zida, M. (2016) REDD+, transformational change and the promise of performance-based payments: a qualitative comparative analysis. Climate Policy (online first, DOI:10.1080/14693062.2016.1169392).

Crabtree, B. \& Miller, W. (1999). A template approach to text analysis: developing and using codebooks. In: Doing Qualitative Research, eds. B. Crabtree \& W. Miller, pp. 163-177. Newbury Park, CA, USA: Sage.

Cronin, T., Santoso, L., Di Gregorio, M., Brockhaus, M., Mardiah, S. \& Muharrom, E. (2016) Moving consensus and managing expectations: media and REDD+ in Indonesia. Climatic Change 137: $57-70$

Dermawan, A., Petkova, E., Sinaga, A.C., Muhajir, M. \& Indriatmoko, Y. (2011) Preventing the Risks of Corruption in REDD+ in Indonesia. Bogor, Indonesia: CIFOR.

Di Gregorio, M., Brockhaus, M., Cronin, T., Muharrom, E., Santoso, L., Mardiah, S. \& Büdenbender, M. (2013) Equity and REDD+ in the media: a comparative analysis of policy discourses. Ecology and Society 18: 39.

Dkamela, G.P. (2011) The Context of REDD+ in Cameroon: Drivers, Agents and Institutions. Bogor, Indonesia: CIFOR.

Dkamela, G.P., Brockhaus, M., Djiegni, F.K., Schure, J. \& Mvondo, S.A. (2014) Lessons for REDD+ from Cameroon's past forestry law reform: a political economy analysis. Ecology and Society 19: 30 .
Fereday, J. \& Muir-Cochrane, E. (2006) Demonstrating rigor using thematic analysis: a hybrid approach of inductive and deductive coding and theme development. International fournal of Qualitative Methods 5: 80-92.

Fischer, F., Miller, G.J. \& Sidney, M.J. (2007) Handbook of Public Policy Analysis - Theory, Politics, and Methods. Boca Raton, FL, USA: CRC Press, Taylor \& Francis Group.

Gebara, M.F., Fatorelli, L., May, P. \& Zhang, S. (2014) REDD policy networks in Brazil: constraints and opportunities for successful policy making. Ecology and Society 19: 53.

Global Witness (2011) Forest Carbon, Cash E Crime: The Risk of Criminal Engagement in REDD+. London, UK: Global Witness.

Harvey, C.A., Dickson, B. \& Kormos, C. (2010) Opportunities for achieving biodiversity conservation through REDD. Conservation Letters 3: 53-61.

Herold, M., Verchot, L.V., Angelsen, A., Maniatis, D. \& Bauch, S. (2012) A Step-mise Framemork for Setting REDD + Forest Reference Emission Levels and Forest Reference Levels. Bogor, Indonesia: CIFOR.

Huettner, M. (2012) Risks and opportunities of REDD+ implementation for environmental integrity and socio-economic compatibility. Environmental Science and Policy 15: 4-12.

Indrarto, G.B., Murharjanti, P., Khatarina, J., Pulungan, I., Ivalerina, F., Rahman, J., Prana, M.N., Resosudarmo, I.A.P. \& Muharrom, E. (2012) The Context of REDD+ in Indonesia: Drivers, Agents, and Institutions. Bogor, Indonesia: CIFOR.

Kambire, H. W., Djenontin, I. N. S., Kabore, A., Djoudi, H., Balinga, M. P. B., Zida, M. \& Assembe-Mvondo, S. (2015). La REDD+ et l'Adaptation aux Changements Climatiques au Burkina Faso. Bogor, Indonesia: CIFOR.

Kengoum, D.F., Kabamba, F. M. \& Mbelu, A. (2014) REDD+ Policies in the Media: The Case of the Written Press in Democratic Republic of Congo. Bogor, Indonesia: CIFOR.

Kengoum, D.F. (2011) REDD+ Politics in the Media: A Case Study from Cameroon. Bogor, Indonesia: CIFOR.

Korhonen-Kurki, K., Brockhaus, M., Duchelle, A.E., Atmadja, S., Pham, T.T. \& Schofield, L. (2013) Multiple levels and multiple challenges for measurement, reporting and verification of REDD+. International fournal of the Commons 7: 344-366.

Kweka, D., Carmenta, R., Hyle, M., Mustalahti, I., Dokken, T. \& Brockhaus, M. (2015). The Context of REDD+ in Tanzania: Drivers, Agents and Institutions. Bogor, Indonesia: CIFOR.

Larson, A.M., Brockhaus, M., Sunderlin, W.D., Duchelle, A., Babon, A., Dokken, T., Pham, T.T., Resosudarmo, I.A.P., Selaya, G. \& Awono, A. (2013) Land tenure and REDD+: the good, the bad and the ugly. Global Environmental Change 23: 678-689.

Lestrelin, G., Trockenbrodt, M., Phanvilay, K., Thongmanivong, S., Vongvisouk, T., Pham, T.T. \& Castella, J.-C. (2013) The Context of REDD+ in the Lao People's Democratic Republic: Drivers, Agents and Institutions. Bogor, Indonesia: CIFOR.

Loft, L., Ravikumar, A., Gebara, M.F., Pham, T.T., Resosudarmo, I.A.P., Assembe-Mvondo, S., Tovar, J.G., Mwangi, E. \& Andersson, K. (2015) Taking stock of carbon rights in REDD+ candidate countries: concept meets reality. Forests 6: 1031-1060.

Luttrell, C. \& Fripp, E. (2015) Lessons from Voluntary Partnership Agreements for REDD+ Benefit Sharing. Bogor, Indonesia: CIFOR.

Luttrell, C., Loft, L., Gebara, M.F., Kweka, D., Brockhaus, M., Angelsen, A. \& Sunderlin, W.D. (2013) Who should benefit from REDD+? Rationales and realities. Ecology and Society 18: 52. 
May, P.H., Millikan, B. \& Gebara, M.F. (2011) The Context of REDD+ in Brazil: Drivers, Agents, and Institutions. Bogor, Indonesia: CIFOR.

Mpoyi, A.M., Nyamwoga, F.B., Kabamba, F.M. \& AssembeMvondo, S. (2013) The Context of REDD+ in the Democratic Republic of Congo: Drivers, Agents, and Institutions. Bogor, Indonesia: CIFOR.

Müller, R., Pacheco, P. \& Montero, J.C. (2014) The Context of Deforestation and Forest Degradation in Bolivia: Drivers, Agents and Institutions. Bogor, Indonesia: CIFOR.

Norwegian Agency for Development Cooperation (NORAD) (2013) Real-time Evaluation of Normay's International Climate and Forest Initiative: Contribution to Measurement, Reporting and Verification. Oslo, Norway: NORAD.

Ochieng, R.M., Visseren-Hamakers, I.J., Arts, B., Brockhaus, M. \& Herold, M. (2016) Institutional effectiveness of REDD+ MRV: countries progress in implementing technical guidelines and good governance requirements. Environmental Science E Policy 61: 42 52.

Paudel, N.S., Khatri, D.B., Khanal, D.R. \& Karki, R. (2013) The Context of REDD+ in Nepal: Drivers, Agents, and Institutions. Bogor, Indonesia: CIFOR.

Pham, T.T., Moeliono, M., Nguyen, T.H., Nguyen, H.T. \& Vu, T.H. (2012) The Context of REDD+ in Vietnam: Drivers, Agents and Institutions. Bogor, Indonesia: CIFOR.

Pham, T.T., Brockhaus, M., Wong, G., Dung, L.N., Tjajadi, J.S., Loft, L., Luttrell, C. \& Mvondo, S.A. (2013) Approaches to Benefit Sharing: A Preliminary Comparative Analysis of 13 REDD+ Countries. Bogor, Indonesia: CIFOR.

Pham, T.T., Gregorio, M.D., Carmenta, R., Brockhaus, M. \& Le Ngoc, D. (2014) The REDD+ policy arena in Vietnam: participation of policy actors. Ecology and Society 19: 22.

Piu, H.C. \& Menton, M. (2013) The Context of REDD+ in Peru: Drivers, Agents and Institutions. Bogor, Indonesia: CIFOR.

Ravikumar, A., Larson, A.M., Duchelle, A.E., Myers, R. \& Gonzales Tovar, J. (2015) Multilevel governance challenges in transitioning towards a national approach for REDD+: evidence from 23 subnational REDD+ initiatives. International fournal of the Commons 9: 1.

Seymour, F. \& Angelsen, A. (2012) Summary and conclusions: REDD+ without regrets. In: Analysing REDD+: Challenges and Choices, eds. A. Angelsen, M. Brockhaus, W.D. Sunderlin \& L.V. Verchot, pp. 317-334. Bogor, Indonesia: CIFOR.

Sitoe, A., Salomão, A. \& Wertz-Kanounnikoff, S. (2012) The Context of REDD+ in Mozambique: Drivers, Agents and Institutions. Bogor, Indonesia: CIFOR.

Sunderlin, W.D., Ekaputri, A.D., Sills, E.O., Duchelle, A.E., Kweka, D., Diprose, R., Doggart, N., Ball, S., Lima, R., Enright, A., Torres, J., Hartanto, H. \& Toniolo, A. (2014) The Challenge of Establishing REDD+ on the Ground: Insights from 23 Subnational Initiatives in Six Countries. Bogor, Indonesia: CIFOR

Thorpe, A. \& Ogle, L. (2011) Staying on Track: Tackling Corruption Risks in Climate Change. New York, NY, USA: United Nations Development Programme.

Vatn, A. \& Vedeld, P. (2011) Getting Ready! A Study of National Governance Structures for REDD+. Noragric Report No. 59. Aas, Norway: Norwegian University of Life Sciences (UMB).

Wertz-Kanounnikoff, S. \& Angelsen, A. (2009) Global and national REDD+ architecture: linking institutions and actions. In: Realising REDD+: National Strategy and Policy Options, eds. A. Angelsen, M. Brockhaus, M. Kanninen, E. Sills, W.D. Sunderlin \& S. Wertz-Kanounnikoff, pp. 13-24. Bogor, Indonesia: CIFOR.

Wieland, P. (2013) Building carbon rights infrastructure with REDD+ incentives: a multi-scale analysis in the Peruvian Amazon. The Environmental Law Reporter 13: 1026910287.

Wong, G., Angelsen, A., Brockhaus, M., Carmenta, R., Duchelle, A., Leonard, S., Luttrell, C., Martius, C. \& Wunder, S. (2016) Resultsbased Payments for REDD+: Lessons on Finance, Performance, and Non-Carbon Benefits. Bogor, Indonesia: CIFOR. 